\title{
Ревизија и отпис библиотечких фондова: искуства Градске библиотеке у Новом Саду
}

\author{
Данијела Д. Добретић \\ danijela.m.dobretic@gmail.com \\ Оливера М. Топалов \\ oliveratopalov@yahoo.com \\ Андреј С. Радуловић \\ orpheusdoonovisad@gmail.com \\ Градска библиотека у Новом Саду
}

\begin{abstract}
Сажетак
У раду ће бити речи о искуствима Градске библиотеке у Новом Саду (ГБНС) у самом процесу припреме за ревизију и у току ревизије и расхода, као и о проблемима и недоумицама који су се тада јављали. Биће представљен, такође, основни преглед законских прописа и стандарда за ревизију и расход у јавним библиотекама. Ревизија и отпис библиотечке грађе у ГБНС обавља се редовно и по законској регулативи. Целокупан фонд ГБНС, са преко 550.000 публикација, налази се у двадесет и седам огранака који постоје у њеном саставу и Закон у овом случају предвића ревизију најмање једном у десет година. Имајући ово у виду, као и чињеницу да публикације неминовно застаревају, поред свих редовних и додатних послова на унапрећењу библиотечке делатности, ГБНС за десет година тешко, и уз велике напоре, спроводи ревизију целокупног фонда. Највећи проблем настаје дефинисањем и препознавањем расхода само у оквиру ревизије.
\end{abstract}

Кључне речи: ревизија, Градска библиотека у Новом Саду, Обрадно одељење, Набавно одељење, обрт фонда, групно инвентарисање, отпис, расход

\section{Увод}

Ревизија и отпис библиотечко-информационе грађе важни су, колико за библиотекаре, толико и за кориснике. После поступка ревизије и отписа морају се добити прецизне информације о квантитативном и квалитативном стању фонда. Градска библиотека у Новом Саду (ГБНС) их редовно обавља, у складу са законским регулативама, и у прилогу ће бити речи о разликама у пракси и теорији на основу стечених искустава. Циљ овог текста је да се укаже на недоумице и проблеме на које се наилазило у току ревизије и неусаглашености смерница и праксе. Рад сваке јавне библиотеке у великој мери може допринети разумевању проблема, међубиблиотечком повезивању и размени искустава, као и указивању на актуелне недостатке и потребе везане за процесе рада и ревизије.

Ревизија је регулисана Законом о библиотечко-информационој делатности ${ }^{1}$ и Правилником о инвентарисању, обради, ревизији и отпису библиотечко-информационе грађе и извора, као и вођењу евиденције о библиотечко-информационој грађи и изворима. ${ }^{2}$ Ова акта имају за циљ да дефинишу и уобличе процесе рада и ревизије. Редовна ревизија и отпис, односно,

\footnotetext{
1 Министарство културе и информисања Републике Србије, „Закон о библиотечко информационој делатности", Службени іласник PC бр. 52 (2011), преузето 15. 5. 2019, www.kultura.gov.rs

2 Министарство културе и информисања Републике Србије, „Правилник о ревизији и отпису библиотечко-информационе грађе и извора", Службени Гласник РС бр. 47 (2013).
} 
расход књига из фондова, према установљеним правилима и нормама, неопходни су, како се не би дошло у ситуацију да се не зна шта се у фондовима налази. Стање на полицама требало би да одговара оном у електронском каталогу. ГБНС обавља ревизију и расход електронски у програмском пакету БИСИС. ${ }^{3}$

\section{Законски оквири ревизије фондова у ГБНС и њена искуства и специфичности}

Требало би напоменути да актуелни правилник подразумева расход само у току ревизије, што успорава и отежава рад библиотекарима. Позната је чињеница да су библиотеке у Србији у дефициту са основним простором за актуелне наслове, а нарочито за депозит књига. ГБНС поседује више магацина, где се, у складу са законом, оне које су предвиђене за расход складиште. Спискови ових публикација прослеђују се Библиотеци Матице српске и Народној библиотеци Србије и чека се одговор на понуду. У пракси се показало да је врло мали број понуђених наслова потребан националним библиотекама, јер се оне већ налазе у њеним фондовима. Преостали део књига (издвојени, дупли или неактуелни примерци из ГБНС) чувају се за поклон новим библиотекама у настајању, за донације приликом хуманитарних акција, а најмањи део, оне у лошем стању, одстрањују се рециклажом.

Стање књижног фонда Градске библиотеке у Новом Саду, на крају 2019. године, било је 553.942, библиографске јединице, ${ }^{4}$ што је према Правилнику о ревизији и отпису библиотечко-информационе грађе и извора сврстава у четврту групу, у којој би ревизија комплетног фонда морала бити обављена једном у десет година. ${ }^{5}$ У овом случају, искуства говоре, да би процес ревизије у ГБНС текао у круг у свих двадесет и седам огранака и не би се уклапао у временски прописане оквире, без великог труда и рада стручних радника. Из тог искуства може се извући и потреба за усаглашавањем важећег Закона са реалним стањем и потребама библиотека.

У складу са Правилником о ревизији и отпису библиотечко-информационе грађе и извора, њу расписује управник библиотеке, који том приликом именује комисију. ${ }^{6}$ У ГБНС комисија за ревизију, поред председника, по једног члана из Одељења за попуњавање фондова и инвентарисање књига, Одељења за обраду и библиографска истраживања, има и једног информатичара и једног или више чланова са одељења које врше ревизију. На састанцима, комисија је утврђивала план и редослед ревизије фондова, односно огранака, и њихов метод. Дакле, пре него што се приступи ревизији комплетног библиотечог фонда, неопходно је урадити припрему библиотечке грађе, која би обезбедила њену квалитетнију реализацију.

Смештај фонда у ГБНС је уређен по систему Универзалне децималне класификације (УДК). Фондови су у отвореном приступу. Овакав смештај фонда захтева стално праћење промена и препорука стручних тела и међународних стандарда, чиме се бави Одељење за обраду и библиографска истраживања. Увођењем нових УДК бројева, почев од 1995. године, у фонду су били заступљени и стари и нови УДК бројеви за књижевност, религију, лингвистику, историју. Овакво стање могло се толерисати неко време, али, са увођењем бар-кода и бар-код налепница, морале су се извршити неопходне интервенције у библиографским записима. Ове радње су саставни део припрема за ревизију. Њена специфичност је у томе што је цео фонд ретроактивно прегледан и делимично рекласификован (кроз електронску базу), што је морало

\footnotetext{
3 Bisis, preuzeto 15. 5. 2019, www.bisis.rs.

${ }_{4}^{4}$ Градска библиотека у Новом Саду, Извешйај о раgу и йословању за 2019. іолину (Нови Сад: Градска библиотека, 2019$), 23$.

${ }^{5}$ Библиотеке које имају преко 300.000 јединица библиотечко-информационе грађе и извора редовну ревизију обављају најмање једанпут у десет година. - Министарство културе и информисања Републике Србије, „Правилник о ревизији и отпису библиотечко-информационе грађе и извора".

${ }^{6}$ Министарство културе и информисања Републике Србије, „Правилник о ревизији и отпису библиотечко-информационе грађе и извора".
} 
бити урађено пре почетка ревизије. У електронским базама ова припрема је подразумевала уједначавање библиографских записа. Такав приступ је неопходан зато што бар-код и бар-код налепница морају садржати нови УДК број и одговарајућу сигнатуру. Ради рационализације послова, уједначавање записа вршило се за сваки огранак посебно, селектовањем само записа из фонда који је предвиђен за ревизију. Овде се наилазило на проблем неусаглашености. Наиме, дешавало се да се, у току ревизије, расходују књиге у чијем је запису, у оквиру припрема, вршена интервенција. Како је законски регулисано да се расход може спровести само у оквиру овог поступка, као што је већ споменуто, у овом случају, практично се анулира већ одрађен посао и узалуд је утрошено време. У многим записима, у које се улазило током припреме, долазило је до расхода свих публикација. Делимично решење за овај проблем ГБНС је пронашла у ванредним ревизијама и расходима, које су спроведене при пресељењу огранака, реновирању просторија, санирању кварова итд. ${ }^{7}$ Оно што иде у прилог потреби чешћег расхода јесте и чињеница да већи обрт и искоришћеност имају фондови који садрже актуелна издања.

Процес ревизије и расхода који се примењује у Србији није познат у западним земљама. У Смерницама за библиошеке gржавних оgељења, Бихани пише: „Расход ресурса (књига) је неопходност за одржавање активног и корисног фонда. Контрола његовог квалитета постиже се уклањањем застареле, нетачне и дотрајале грађе. Одређену грађу, на пример, правне текстове, можда би требало трајно чувати. У политици развоја фонда требало би прецизирати коју грађу никада не би требало расходовати или је расходовати само уз секундарну ревизију". ${ }^{8}$

Ови послови су, дакле, углавном, препуштени самим библиотекама, смернице нису стриктне ни условне. Постоје правилници којим се свака установа води. У страним референцама се често спомиње и термин - сналажење у хоgу, који се и код нас употребљава. По препорукама ALA-e (American Library Assocation) 9 библиотека, у континуитету, повлачи публикације из фонда, заснивајући своје одлуке на многим факторима, укључујући датум објављивања, учесталост тиража, интересе заједнице и доступност новијих или валиднијих материјала. Публикације које обрађују завичајну историју су изузетак, као и неки класици и награђиване дечје књиге. Белетристика која је некада била популарна, али више није тражена и научнофантастичне књиге које више нису актуелне, повлаче се из фонда. У питању је слободан отпис. Y IFLA/UNESCO смерницама за јавне библиотеке ${ }^{10}$ стоји да је фонд библиотеке динамичан ресурс, да захтева константан прилив нових и одлив застарелих публикација, да би се одржао значај фонда у заједници у којој се налази. Као што се може видети из свега овога, у свету се мање пажње поклања процесу отписа неактуелних књига; самим тим се поједностављује набавка нових, квалитетних и актуелних наслова.

У ГБНС књиге за отпис, неактуелне или неупотребљиве публикације елиминише комисија коју је именовала управа библиотеке. Води се рачуна о ретким или јединим примерцима у библиотеци, награђиваним публикацијама, културним добрима, која се не могу отписати, као и завичајној грађи. У оквиру тог посла, неактуелне публикације се у ГБНС могу пресиглирати из једног огранка за други, а обавља га и контролише Одељење за попуњавање фондова и инвентарисање.

Дешава се да библиотекари, због велике потражње за „лаким“ популарним издањима, њих изостављају из расхода. Сматрамо да је такав принцип погрешан, из следећих разлога

\footnotetext{
7 Министарство културе и информисања Републике Србије, „Правилник о ревизији и отпису библиотечко-информационе грађе и извора".

8 Sanjay K. Bihani, "Section 6, Collection Development", Guidelines for Liberies of Goverment departments, 25/29 (2008), preuzeto 15 5. 2019, https://archive.ifla.org/VII/s4/pubs/Profrep106.pdf.

9 American Library Association, ALA, Preuzeto 15. 5. 2019, https://www.ala.org.

10 International Federation of Library Associations and Institutions IFLA, "The public library service: IFLA/UNESCO guidelines for development "(München: IFLA Publikacions, 2001), preuzeto 25. 1. 2020, https://www.ifla.org/files/assets/hq/publications/archive/the-public-library-service/publ97.pdf.
} 
- продукција таквих књига је у све већем порасту, набавља се у свакој јавној набавци, а притом стиже у великом броју и путем поклона. Иако она може повећати обрт фонда, мишљења смо да библиотекари ипак морају формирати фонд према строжим вредносним критеријумима, а не само према жељама љубитеља овакве литературе. Требало би, дакле, одлучити да ли је битнији обрт фонда или квалитет литературе која се нуди корисницима. Решење је вероватно у налажењу баланса. Данас, је нажалост, продукција овакве литературе велика и она је постала неизбежност јавних библиотека. Велики део фонда чини управо профана литература, попут популарне психологије, криминалистичких романа, љубавних романа, еротских сензација, епске фантазије и сличне грађе, која би, свакако, требало да нађе место у свакој библиотеци, само у далеко мањем броју. ${ }^{11}$

Осим на садржај дела, потребно је, приликом набавке, обратити пажњу и на квалитет повеза. Свака публикација може да издржи, у просеку, од 60 до 100 позајмљивања, поготово дечја књига и сликовнице (тачни подаци не постоје и не воде се ни у једној библиотеци).. ${ }^{12}$

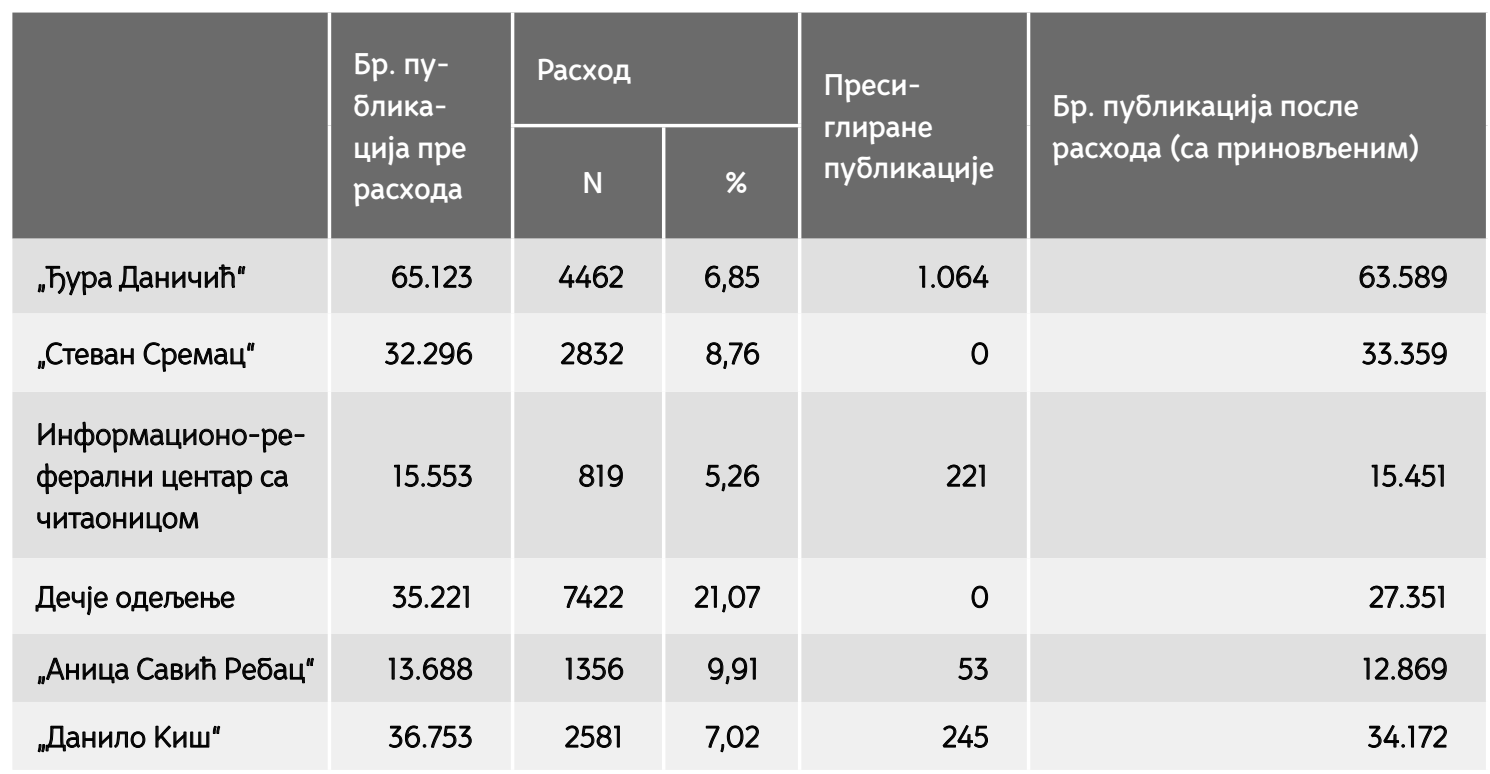

Табела 1. Стање фонда по огранцима који су завршили ревизију13

\section{Ревизија целокупног фонда ГБНС са увођењем бар-кода}

У датој табели се, у односу на почетни фонд огранака који су урадили ревизију, види велики проценат расходованих публикација. То се најбоље може видети по расходу огранака „Ђура Даничић“, „Стеван Сремац“ и „Данило Киш“. Разлог томе је, између осталог, и велики распон између две редовне ревизије, недовољно простора за смештај књига, смањење броја

\footnotetext{
11 Библиотекари и издавачи су, последњих година, различитим приликама, у медијима или на стручним скуповима (најчешће по објављивању резултата републичког откупа књига за библиотеке) разматрали ово питање. Видети нпр. „Набавна политика библиотека и спровођење откупа публикација за библиотеке Министарства културе и информисања Републике Србије" (Градска библиотека Панчево, 7. септембар 2015), преузето 10. 6. 2019, https://citaliste.rs/casopis/br27/nabavna_politika.pdf

12 Konraud Umlauf, Nabavna politika - radionica (Beograd: Goethe Institut, 2005), preuzeto 10. 9. 2019, https://www.nb.rs/view_file.php?file_id=1105

13 Подаци за табелу преузети из претраживања базе података Градске библиотеке у Новом Саду, сукцесивно, у периоду од 2013. до 2019. године.
} 
запослених ${ }^{14}$ оптерећеност колега честим заменама у другим огранцима. У целој мрежи ГБНС, а посебно на Дечјем одељењу, у току расхода нарочито се обраћала пажња на актуелност, дотрајалост и физичко стање публикација, посебно сликовница.

Библиотеке које раде у COBISS-y, ${ }^{15}$ имају на располагању текуће одржавање, као и тестну базу, која се инсталира на недељу дана. Комплетна процедура ревизије може се обавити потпуно аутоматизовано и у складу са Законом. Библиотекама чији софтвери не пружају овакве могућности, попут БИСИС-а, потребно је више времена да би обавиле овај одговорни посао, да не говоримо о неким мањим библиотекама које још увек немају никакав програм за библиотечко пословање. Оне морају да се ослоне на класичан начин рада који јесте поуздан, али је дуготрајан.

Када је реч о методама ревизије, било би најбоље, ако је могуће, да се расход врши помоћу бар-код читача. Једноставније је и одузима мање времена. Узимајући у обзир, појединачно, послове око ревизије и увођења бар-кода, у ГБНС је одлучено да се ова два различита процеса обједине, раде истовремено, како би се оптимализовало време и несметано обављали остали редовни послови. Ревизија целокупног фонда ГБНС, са увођењем бар-кода, започета је у највећем огранку „Ђура Даничић“, 2014. године.

Предност аутоматизације огледа се у могућности да се једном урађеном интервенцијом у запису обухвате сви инвентарни бројеви у огранцима који су имали идентичне публикације. То значи да је свако наредно претраживање, које се спроводило ради сређивања фонда за ревизију у следећем огранку, показивало мањи број записа за исправку. При наредним претрагама за остале огранке који су имали исте публикације, овако уређени записи се нису појављивали, што је умногоме олакшало даљи рад. Ове интервенције могле су да се ураде програмском подршком или појединачно, улазећи у сваки запис. Избор је зависио од комплексности интервенција и од броја погодака записа.

Све ревизије у огранцима ГБНС вршене су уз минималне промене радног времена и уз свакодневни рад. Редовани процес рада није нарушаван, али су се сви запослени додатно ангажовали да би се избегло затварање библиотеке због ревизије, што је код корисника прилично непопуларно.

У току сваке појединачне ревизије, у Одељењу за обраду и библиографска истраживања праћен је њен ток, тако да су, у договору с огранцима у којима се врши ревизија, допуњаване предметне одреднице, у фреквентним публикацијама, најчешће у делу фонда с књижевним критикама. Тако је у процесу ревизије искоришћена могућност да се публикације и садржински додатно допуне.

У току припрема за ревизију договорено је да се одвоји српска књижевност од осталих књижевности бивше СФР), тако да су формиране две нове групе, које су издвојене из постојеће групе југословенске књижевности, а то су: српска књижевност (821.163.41) и јужнословенска књижевност (хрватска, босанска, црногорска, македонска, словеначка), са бугарском књижевношћу (821.163.4). У оквиру овог посла требало је публикације књижевника који су писали и стварали у држави Југославији раздвојити на српску или јужнословенску књижевност. Како у време када је исказана потреба за овом врстом посла није постојала никаква национална препорука, овај посао у Обрадном одељењу захтевао је доста истраживања, ишчитавања интервјуа аутора, коришћење Узајамно библиографско-каталошке базе података COBISS.SR, ${ }^{16}$ OPAK ${ }^{17}$ база библиотека у окружењу, енциклопедија, приручне литературе.

\footnotetext{
${ }^{14}$ Министарство културе и информисања Републике Србије, „Закон о начину одређивању максималног броја запослених у јавном сектору", Службени іласник РС бр. 68 (2015); 81 (2016) - одлука УС и 95 (2018), преузето 15. 5. 2019, http://mduls.gov.rs/ propisi/zakoni-u-primeni/.

${ }_{15}$ COBISS.SR, preuzeto 15. 5.2019, http://www.vbs.rs/scripts/cobiss?ukaz=getid\&lani=sc.

16 Isto.

17 OPAC - Online Public Access Catalog.
} 
Ревизије са увођењем бар-кода, у Градској библиотеци у Новом Саду, континуирано се настављају на целокупном фонду као обавеза регулисана Законом о библиотечко-информационој делатности.

\section{Закључак}

Ревизија је регулисана законским актима и обавезна је за све библиотеке у Србији. Правилник о ревизији и отпису библиотечко-информационе грађе и извора наглашава да се њоме „утврђује стварно бројчано и физичко стање инвентарисане библиотечко-информационе грађе и извора која је власништво библиотеке, правна заштита и актуелност библиотечких фондова“. У целој мрежи ГБНС, а посебно на Дечјем одељењу, у току расхода нарочито се обраћала пажња на актуелност, дотрајалост и физичко стање публикација. У датој табели се види велики проценат расходованих публикација, што је неминовно када је распон између две редовне ревизије велики, а нема довољно простора за смештај нових књига.

Јавне библиотеке које имају већи број огранака труде се да заврше ревизију у законски одређеном року, тако да се годинама њихов фонд означава као „ревизија у току“. Библиотека која има већи број огранака, као ГБНС, а мањак стручних радника, годишње може да заврши овај одговоран посао у највише два до три огранка и то уз додатну активност запослених. Препознавање расхода само у оквиру ревизије отежава пословање библиотека те је потребно чешће обнављање и актуелизација фонда расходом.

Иако постоје смернице за ревизију и расход, стварно стање, са развојем библиотечког пословања и информационих технологија, захтева прилагођавање у циљу ефикаснијег и бољег пословања целокупног библиотечког система. Свака библиотека самостално, у складу са средствима којима располаже, аутоматизује своје пословање, што директно утиче на њихов рад и када је ревизија у питању, а што је још једно од отворених питања које би требало што пре решити. ${ }^{18}$

\section{Литература и извори:}

1. American Library Association. ALA. Preuzeto 15. 5. 2019. https://www.ala.org

2. Bihani, Sanjay K. "Section 6, Collection Development". Guidelines for Libraries of Government departments 106 (2008): 25-29. Preuzeto 15. 5. 2019. https://archive.ifla.org/VII/s4/pubs/Profrep106.pdf.

3. Bisis. Preuzeto 15. 5. 2019. www.bisis.rs

4. COBISS.SR. Preuzeto 15. 5. 2019. https://sr.cobiss.net/.

5. Gradska biblioteka u Novom Sadu. Izveštaj o radu i poslovanju za 2019 godinu. Novi Sad: Gradska biblioteka, 2019.

6. International Federation of Library Associations and Institutions. "The public library service: IFLA/ UNESCO guidelines for development". München: IFLA Publications,2001. Preuzeto 25. 1. 2020. https://www.ifla.org/files/assets/hq/publications/archive/the-public-library-service/publ97.pdf.

7. Ministarstvo kulture i informisanja Republike Srbije. „Pravilnik o reviziji i otpisu bibliotečko-informacione građe i izvora". Službeni glasnik RS br. 47 (2013).

8. Ministarstvo kulture i informisanja Republike Srbije. „Zakon o bibliotečko-informacionoj delatnosti". Službeni glasnik RS br. 52 (2011). Preuzeto 15. 5. 2019. www.kultura.gov.rs.

9. Ministarstvo kulture i informisanja Republike Srbije. „Zakon o načinu određivanja maksimalnog broja zaposlenih u javnom sektoru". Službeni glasnik RS br. 68 (2015), 81 (2016) - odluka US i 95 (2018).

Preuzeto 15. 5. 2019. http://mduls.gov.rs/propisi/zakoni-u-primeni/.

\footnotetext{
18 Ово питање и питање ревизија разматрано је на многобројним стручним скуповима. Види: Радионица о ревизији библиотечко-информационе грађе (Београд: НБС, 2019), преузето 10. 9. 2019, https://www.nb.rs/pages/article.php?pf=1\&id=36090\&url=\%2Fpages\%2Farticle.php\%3Fpf\%3D1\%26id\%3D36090.
} 
Добретић Д. и др. „Ревизија и отпис библиотечких фондова...“, 96-102

10. Umlauf Konrad. Nabavna politika - radionica. Beograd: Goethe Institut, 2005. Preuzeto 10. 9. 2019. https://www.nb.rs/view_file.php?file_id=1105

11. Radionica o reviziji bibliotečko-informacione građe. Beograd: NBS, 2019. Preuzeto 15.

5. 2019. https://www.nb.rs/pages/article.php?pf=1\&id=36090\&url=\%2Fpages\%2Farticle. php\%3Fpf\%3D1\%26id\%3D36090

\title{
Revision and Write-Off of Library Materials: Experience of the City Library in Novi Sad
}

\begin{abstract}
Summary
The paper presents the experience of the City Library in Novi Sad (CLNS) in the process of preparation for the revision and during the revision and write-off, as well as the problems and doubts encountered during these procedures. A basic overview of legal regulations and standards for revision and write-off in public libraries is also given. In the City Library in Novi Sad the revision and write-off of library materials are performed regularly and according to the legal regulations. The entire fund of CLNS, consisting of more than 550,000 publications, is located in the twenty-seven branches of this library. According to the law, in cases like this, revision should be performed at least once every ten years. Having in mind this, as well as the fact that publications inevitably outdate, CLNS strives to conduct a revision of the entire fund over a ten-year period. Since it is performed in addition to regular and additional activities from the wide scope of current affairs that a public library deals with, this work requires great effort of library professionals. The biggest problem arises by defining and recognizing write-off only within the revision procedure.
\end{abstract}

Keywords: revision, City Library in Novi Sad (CLNS), Processing Department, Purchasing Department, fund turnover group inventory, write-off 


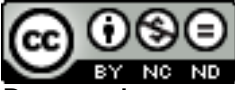

Ревизија и отпис библиотечких фондова: искуства Градске библиотеке у Новом Саду bу Данијела Д. Добретић, Оливера М. Топалов, Андреј С. Радуловић is licensed under a Creative Commons AttributionNonCommercial-NoDerivatives 4.0 International License. 